\title{
STROMBOMONAS CARINATA SP. NOV. AND STROMBOMONAS FERRAZI SP. NOV., TWO NEW EUGLENOPHYCEAE FROM THE STATE OF RIO GRANDE DO SUL, SOUTHERN BRAZIL
}

\author{
Sandra Maria Alves-da-Silva ${ }^{1}$ \\ Carlos Eduardo de Mattos Bicudo ${ }^{2}$
}

Received: 05/12/2001. Accepted: 04/06/2002

\begin{abstract}
RESUMO - (Strombomonas carinata sp. nov. e Strombomonas ferrazi sp. nov., duas novas Euglenophyceae do Estado do Rio Grande do Sul, sul do Brasil). Duas espécies de Strombomonas (Euglenaceae, Euglenophyceae), $S$. carinata e $S$. ferrazi, são descritas e propostas como novas. As unidades amostrais em que foram encontrados os espécimes estudados foram coletadas de um reservatório (reservatório n. 7) localizado no Parque de Proteção Ambiental do Pólo Petroquímico do Sul (29 53'S, 51 $\left.{ }^{\circ} 22^{\prime} \mathrm{W}\right)$, em Triunfo, Estado do Grande do Sul, sul do Brasil. Características físicas e químicas da água do reservatório onde ambas as espécies foram coletadas são apresentadas.

Palavras-chave - Strombomonas carinata sp. nov., Strombomonas ferrazi sp. nov., Euglenophyceae, Rio Grande do Sul, Brasil

ABSTRACT - (Strombomonas carinata sp. nov. and Strombomonas ferrazi sp. nov., two new Euglenophyceae from the state of Rio Grande do Sul, southern Brazil). Two species of Strombomonas (Euglenaceae, Euglenophyceae), $S$. carinata and $S$. ferrazi, are described and proposed as new to science. Sample units from which specimens were studied were collected from a reservoir (reservoir n. 7) located in an Environment Protection Park ("Parque de Proteção Ambiental") in the South Petrochemical Station ("Pólo Petroquímico do Sul”) (2953'S, 51²2'W), in Triunfo, state of Rio Grande do Sul, southern Brazil. Physical and chemical data of the water of the system from which the two species were collected are presented.
\end{abstract}

Key words - Strombomonas carinata sp. nov., Strombomonas ferrazi sp. nov., Euglenophyceae, Rio Grande do Sul State, Brazil

\footnotetext{
1 Museu de Ciências Naturais, Núcleo de Vegetais Inferiores, C. Postal 1188, CEP 90610-000, Porto Alegre, RS, Brazil (gcferraz@cpovo.net)

2 Instituto de Botânica, Seção de Ficologia, C. Postal 4005, CEP 01061-970, São Paulo, SP, Brazil.
} 


\section{Introduction}

Deflandre (1930) proposed separation of the species at that time classified in the Subsection Acuminatae Deflandre 1926 of Section Caudatae Deflandre 1926 of genus Trachelomonas to constitute the new genus Strombomonas. According to the original proposition, both diagnostic characteristics of Strombomonas referred to the lorica, i.e. collar without a clear-cut distinction from the remainder of the lorica, and the posterior pole ending in a tail-like projection (Deflandre 1930). There is no difference between the protoplasts of representantives of both genera. Comparison of the ultrastructure and chemical composition of the loricas of the two genera demonstrated the common existence of many particles adherent to the surface of the loricas of Strombomonas, in contrast with their total absence in Trachelomonas (Tell \& Conforti 1984; 1988; Conforti et al. 1994). Dunlap et al. (1986) concluded that the microarchitecture and the chemical composition of the lorica of $S$. conspersa (Pascher) Deflandre are very similar to those of many species of Trachelomonas.

Variation of the shape of the lorica in sample populations of Strombomonas is of somewhat common occurrence in nature and may include certain forms that could be understood intermediate between the two genera above, to such an extent that Balech (1944) and Bourrelly (1970) stated that separation of both genera may be very difficult or at least obscure. The present moment thus calls for an urgent need for a suitable revision of the boundaries of the circumscriptions of both Strombomonas and Trachelomonas through definition of the diagnostic features of each genus.

The present work aims to provide a description of two species of Strombomonas, which are simultaneously proposed as new to science.

\section{Material and methods}

Monthly gatherings were made from February 1995 to March 1996 by using a $49 \mu \mathrm{m}$ mesh phytoplankton net at approximately $30 \mathrm{~cm}$ below the water surface and at two collecting stations located in an accumulation reservoir, reservoir n. 7 (Fig. 1), located in an Environment Protection Park in the South Petrochemical Station (29 $\left.53^{\prime} \mathrm{S}, 51^{\circ} 22^{\prime} \mathrm{W}\right)$, in Triunfo, state of Rio Grande do Sul, southern Brazil.

Reservoir n. 7 was dammed in 1982 and is maintained by pipe-lined rain water, the excess of water being deviated to the Caí River. The reservoir is bordered by "maricás", grasses, and sedges and shows many species of aquatic
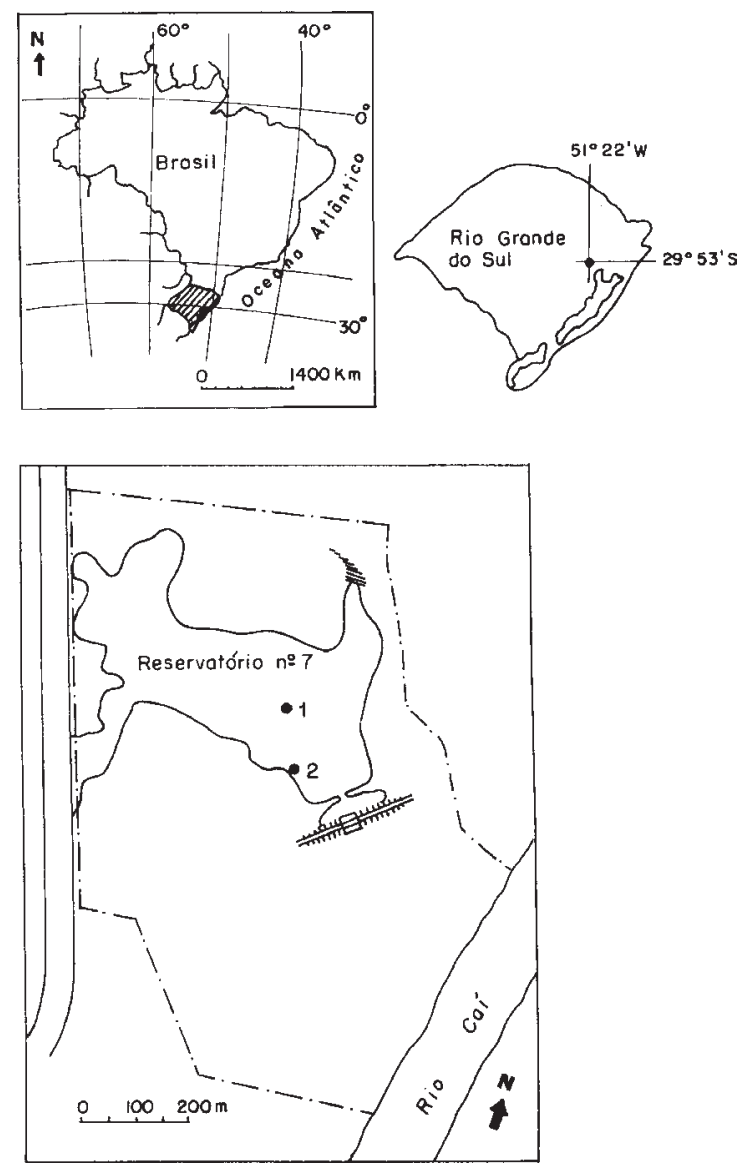

Figure 1. Map showing the reservoir n. 7 and location of collecting stations 1 and 2 . 
macrophytes, among which Salvinia sp. and Ludwigia sp. are dominant.

Still in the field, all 48 sample units collected were divided into two halves, one of which was immediately fixed and preserved with $4 \%$ formalin and the other one kept alive for further study of the morphological features that can be damaged with fixation. Simultaneously, water from the sampling site was collected for physical and chemical analyses. Biological samples were deposited in the Prof. Dr. Alarich R.H. Schultz Herbarium (HAS) of the Rio Grande do Sul Zoobotanical Foundation (Fundação Zoobotânica do Rio Grande do Sul). From the 48 sample units gathered, six contained specimens of $S$. carinata and only one of $S$. ferrazi. The herbarium access numbers of the last seven sample units are HAS26680, HAS26684, HAS26685, HAS26735, HAS26745, HAS26761, and HAS26785.

Methodology of preparation of the loricas for observation at the scanning electron microscope included the following: (1) isolation of loricas by micropipeting under an inverted microscope Wild M40; (2) placing of the loricas on a regular microscope cover slip, which was fixed to the stub with nail polish (Dr. Alain Couté, pers. comm. in January 1994); (3) drying up of the cover slip containing the isolated loricas under a fluorescent bulb; and (4) metalization of the stub with gold-palladium in a Sputtering Bal-Tec SCD-005. Photographs were taken by using a Jeol JSM-5200 scanning electron microscope.

\section{Results and discussion}

Strombomonas carinata Alves-da-Silva \& C. Bicudo

Fig. 2-10, 15-18.

Loricae irregulariter trapeziformes, 29,6-30,5 $\mu \mathrm{m}$ longae, $16,5-19,4 \mu \mathrm{m}$ latae, $\mathrm{R} \mathrm{c} / 1=1,5-1,8$; scissura optica transversali subrectangulari, angulis rotundatis, polo posteriore abrupte attenuato in processum caudalem brevem, mamillanum, ca. $2 \mu \mathrm{m}$ longum; collario cylindraceo, humile, margine irregulari $2-4 \mu \mathrm{m}$ alto, $5,3-7,4 \mu \mathrm{m}$ lato; pariete hyalina usque viridiana, rugosa usque verrucosa, 2 carinae bene notatae, leviter torsae secundum longitudinem loricas; chloroplasti numerosi, discoidei, usque $4 \mu \mathrm{m}$ diametro; flagellum tertiam partem cellulae attingens; pyrenoidea et stigmata non notata.

Holotypus: Lacus artificialis n. 7, leg. Sandra Maria Alves da Silva, II/1995 (HAS26685); figurae nostrae 15-18.

Loricas irregularly trapezoidal, 29.6-30.5 $\mu \mathrm{m}$ long, $16.5-19.4 \mu \mathrm{m}$ wide, R 1/w 1.5-1.8; optical section transversally sub-rectangular, angles rounded; posterior pole suddenly attenuated in a short, mammillate, tail process, ca. $2 \mu \mathrm{m}$ long; collar cylindrical, short, border irregular, $2-4 \mu \mathrm{m}$ tall, 5.3-7.4 $\mu \mathrm{m}$ wide; wall hyaline to greenish, rugulose to verrucose, 2 well marked keels slightly twisted along the length of the lorica; chloroplasts numerous, disc-shaped, up to $4 \mu \mathrm{m}$ in diameter; pyrenoids, flagella, and stigma not observed.

Holotype: Reservoir n. 7, col. Sandra Maria Alves da Silva, February 1995 (HAS26685); SEM photographs n. 15-18.

Summarizing (Tab. 1), the diagnostic features of $S$. carinata are the following: (1) presence of two keels in the lorica wall which are somewhat twisted; (2) transverse section of lorica sub-rectangular, with rounded angles; and (3) chloroplasts large (ca. $4 \mu \mathrm{m}$ diam.) and numerous which give a greenish color to the cell. The species differs from $S$. spiralis (Playf.) Defl. in the trapezoidal shape of the lorica which shows two somewhat twisted keels. Strombomonas spiralis has elliptic lorica, and symmetric helicoidal keels. Strombomonas carinata differs from S. tetraptera Bal. \& Dast. var. tetraptera for in the latter the lorica wall is rugulose and its transverse section quadrangular, with all angles more pronouncedly rounded, while in the former the lorica wall is rugulosegranulose and its transverse section also quadrangular, but with the angles irregularly and relatively less rounded; and from the var. gallica 
Table 1. Comparison of the descriptive characteristics of the lorica and protoplast of Strombomonas carinata sp. nov., S. spiralis (Playfair) Deflandre, S. tetraptera Balech \& Dastugue, and S. subcurvata (Proschkina-Lawrenko) Deflandre var. africana Bourrelly \& Gayral, and S. tetraptera Balech \& Dastugue var. gallica Bourrelly \& Couté.

\begin{tabular}{|c|c|c|c|c|c|}
\hline Characteristic & S. carinata & S. spiralis & $\begin{array}{l}\text { S. subcurvata } \\
\text { var. africana }\end{array}$ & $\begin{array}{l}\text { S. tetraptera } \\
\text { var. tetraptera }\end{array}$ & $\begin{array}{l}\text { S. tetraptera } \\
\text { var. gallica }\end{array}$ \\
\hline Dimensions & $\begin{array}{l}29.6-30.5 \times \\
16.5-19 \mu \mathrm{m}\end{array}$ & $36 \times 21 \mu \mathrm{m}$ & $\begin{array}{l}24-26 \times \\
16-17 \mu \mathrm{m}\end{array}$ & $\begin{array}{c}43-47 \times \\
25-26 \mu \mathrm{m}\end{array}$ & $\begin{array}{l}32-40 \times \\
18-20 \mu \mathrm{m}\end{array}$ \\
\hline $\mathrm{R} 1 / \mathrm{w}$ & $1.5-1.8$ & 1.7 & $1.4-1.5$ & $1.7-1.9$ & $1.7-2.2$ \\
\hline Shape & Trapezoidal & Ellipsoidal & Ovoid & $\begin{array}{l}\text { Angular with } \\
\text { wing-like } \\
\text { expansions }\end{array}$ & Ellipsoidal \\
\hline Collar & $\begin{array}{l}1.8 \mu \mathrm{m} \text { tall, } \\
6-7.4 \mu \mathrm{m} \text { wide }\end{array}$ & $\begin{array}{l}3 \mu \mathrm{m} \text { tall, } \\
6 \mu \mathrm{m} \text { wide }\end{array}$ & - & Short, inclined & Short, inclined \\
\hline Tail process & $1.8 \mu \mathrm{m}$ long & Short & Short & Short & Short, rounded \\
\hline Keels & 2 , twisted & $\begin{array}{l}3-4, \\
\text { helicoidal }\end{array}$ & - & $\begin{array}{l}\text { 4, wing-like, } \\
\text { longitudinal }\end{array}$ & 2, helicoidal \\
\hline Color & Colorless & Colorless & $\begin{array}{l}\text { Yellowish, } \\
\text { brownish }\end{array}$ & Colorless & $\begin{array}{l}\text { Colorless to } \\
\text { yellowish }\end{array}$ \\
\hline Texture & Rugulose & Smooth & Smooth & Rugulose & $\begin{array}{l}\text { Scabrous, } \\
\text { irregularly } \\
\text { granulate }\end{array}$ \\
\hline $\begin{array}{l}\text { Transverse } \\
\text { section }\end{array}$ & $\begin{array}{l}\text { Quadrangular, } \\
\text { angles rounded }\end{array}$ & - & $\begin{array}{l}\text { Transversally } \\
\text { elliptical }\end{array}$ & $\begin{array}{l}\text { Quadrangular, } \\
\text { angles rounded }\end{array}$ & $\begin{array}{l}\text { Quadrangular, } \\
\text { angles rounded }\end{array}$ \\
\hline Chloroplast & $\begin{array}{l}\text { Numerous, } \\
\text { disc-shaped, } \\
\text { ca. } 4 \mu \mathrm{m} \text { diam. }\end{array}$ & - & $\begin{array}{l}\text { Numerous, } \\
\text { rod-shaped, } \\
\text { with double } \\
\text { pyrenoids }\end{array}$ & Oval, small & - \\
\hline
\end{tabular}

Bourr. \& Couté of the same species in its somewhat smaller lorica dimensions and in the quadrangular, with rounded angles transverse section. Finally, Strombomonas subcurvata (Proschk.-Lawr.) Defl. var. africana Bourr. \& Gayr. is clearly distinct from $S$. carinata in its transversely elliptical cross section of the lorica.

Scanning electron microscopy indicated the presence of a conspicuous and irregularly rugulose lorica wall which invariably has some spherical incrustations that give the wall a rugulose-granulose appearance.

Strombomonas ferrazi Alves-da-Silva \& C. Bicudo

Fig. 11-14.

Loricae irregulariter obovatae, 46,2$51,2 \mu \mathrm{m}$ longae, ca. $21,3 \mu \mathrm{m}$ latae, $\mathrm{R}$ c/ 1 ca. 2,2 ; polo posteriore abrupte attenuato in processum caudalem, ca. $9,2 \mu \mathrm{m}$ longo; collario cylindraceo, margine irregulari, ca. $3,7 \mu \mathrm{m}$ alto, ca. $7,4 \mu \mathrm{m}$ lato; pariete castanea, rugosa, 2 carinae longitudinales et leviter obliquae; chloroplasti discoidei, ca. $3 \mu \mathrm{m}$ diametro, pyrenoidea interna presentia; flagellum et estigma non notata.

Holotypus: Lacus artificialis n. 7, leg. Sandra Maria Alves da Silva, VII/1995 (HAS26735); figurae nostrae 11-14.

Lorica irregularly obovate, $46.2-51.2 \mu \mathrm{m}$ long, ca. $21.3 \mu \mathrm{m}$ wide, $\mathrm{R} 1 / \mathrm{w}$ ca. 2.2 ; posterior pole suddenly attenuated in a tail-like process ca. 9.2 $\mu \mathrm{m}$ long; collar cylindrical, border irregular, ca. $3.7 \mu \mathrm{m}$ tall, ca. $7.4 \mu \mathrm{m}$ wide; wall brown, rugulose, 2 longitudinal to slightly twisted keels; chloroplastos disc-shaped, ca. $3 \mu \mathrm{m}$ diam.; internal pyrenoids present; flagelum and stigma not seen. 

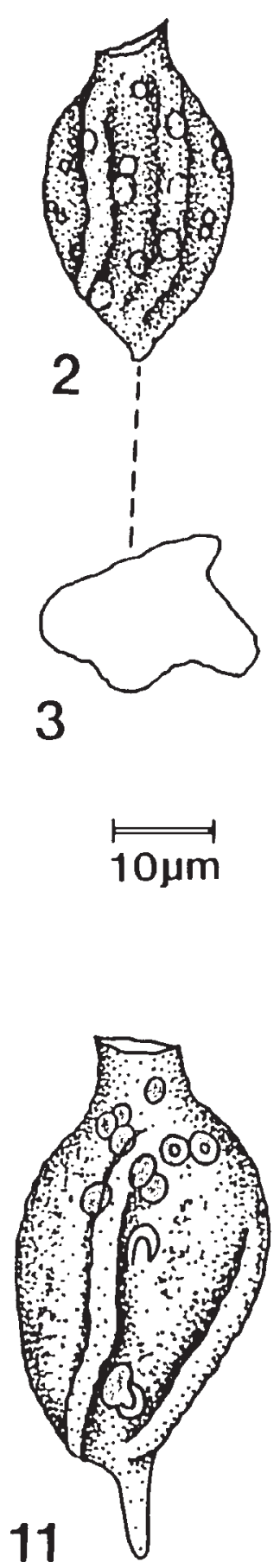
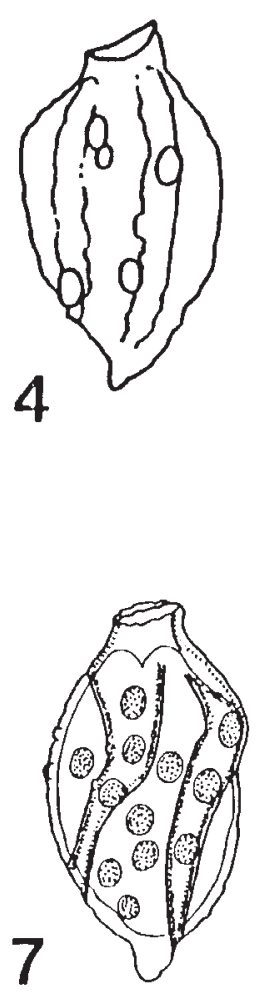

8
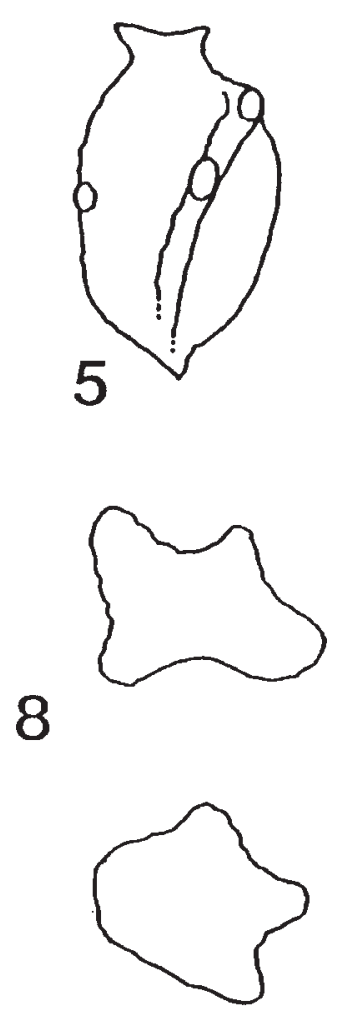

9
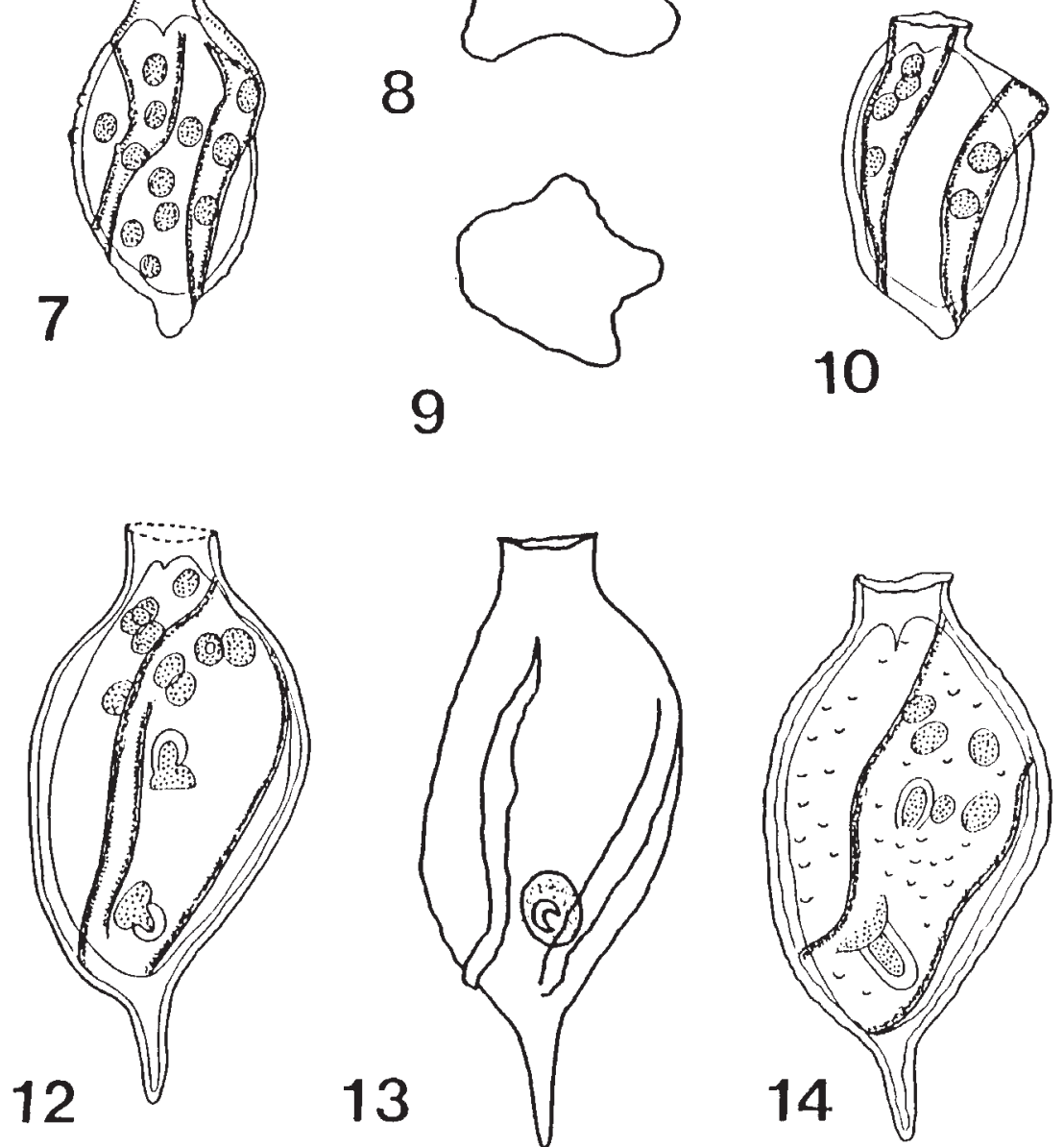

Figures 2-10. Camera-lucida drawings of the lorica of Strombomonas carinata Alves-da-Silva \& C. Bicudo. 3, 8-9. Optical cross section of the lorica. Fig. 11-14. Camera-lucida drawings of the lorica of Strombomonas ferrazi Alves-daSilva \& C. Bicudo. 
Holotype: Reservoir n. 7, col. Sandra Maria Alves da Silva, July 1995 (HAS26685); figures n. 11-14.

The species was named in honor of Prof. Gilberto Ferraz, for his untiring, continuous support to the development of science in the state of Rio Grande do Sul.
From Tab. 2, the diagnostic characteristics of Strombomonas ferrazi are: (1) the irregularly obovate shape of the lorica; (2) the presence of two keels which are slightly twisted along the longitudinal axis of the lorica; and (3) the presence of very conspicuous internal pyrenoids. Strombomonas ferrazi shows some similarities
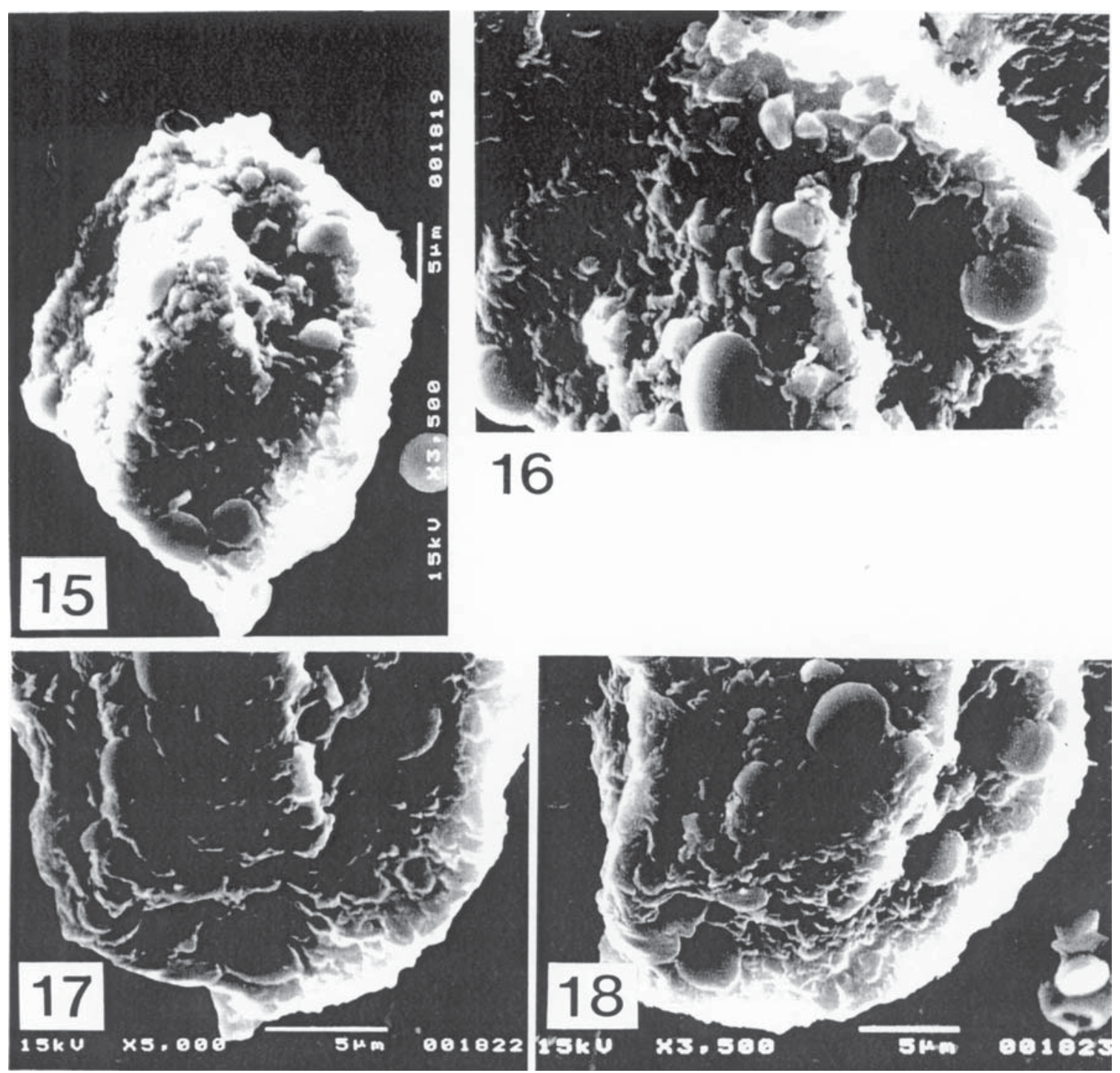

Figures 15-18. SEM photomicrographs of the lorica of Strombomonas carinata Alves-da-Silva \& C. Bicudo. 16. Detail of the anterior pole of lorica and collar; 17-18. Detail of the posterior pole of lorica and tail-like process. 
Table 2. Comparison of the descriptive characteristics of the lorica and protoplast of Strombomonas ferrazi sp. nov., $S$. chodati (Skvortzov) Deflandre, and S. indica Philipose.

\begin{tabular}{llll}
\hline Characteristic & \multicolumn{1}{c}{ S. ferrazi } & \multicolumn{1}{c}{ S. chodati } & \multicolumn{1}{c}{ S. indica } \\
\hline Dimensions & $46.2-51.2 \times 21.3 \mu \mathrm{m}$ & $54-63 \times 20-23.5 \mu \mathrm{m}$ & $63.5-70.5 \times 27-28 \mu \mathrm{m}$ \\
R 1/wca. & ca. 2.2 & $2.2-2.6$ & $2.3-2.6$ \\
Shape & irregularly obovate & $\begin{array}{l}\text { subcilindrical to } \\
\text { irregularly trapezoidal }\end{array}$ & $\begin{array}{l}\text { or triangular } \\
\text { Tail process }\end{array}$ \\
Keels & ca. $9.2 \mu \mathrm{m}$ & long, curved & $19.8-24.6 \mu \mathrm{m}$ \\
Color & 2, twisted & none & 1, twisted \\
Texture & median brown & colorless to yellowish & irregularly granulate \\
Transverse section & rugulose & rugulose & triangular, angles rounded \\
Chloroplast & disc-shaped, numerous & - & poliedric, numerous \\
Pyrenoid & internal & - & double \\
\hline
\end{tabular}

to S. chodati (Skv.) Defl. and S. indica Phil. However, the first one differs from S. ferrazi in the shape of its lorica, which varies from subcylindrical to irregularly trapezoidal, in the low and somewhat broad collar, and in the long and bent to one side caudal process. Finally, Strombomonas indica is distinct from S. ferrazi by the elongate, fusiform-rhomboidal shape of the lorica, the presence of double-pyrenoids, the much longer tail-like process $(19.8-24.6 \mu \mathrm{m})$, the greater cell dimensions $(46.2-51.2 \times 21.3 \mu \mathrm{m})$, and the presence of just one keel.

Strombomonas carinata was collected from sites with low ammonium, nitrite, and nitrate values (Tab. 3). Regarding $\mathrm{pH}$, the species occurred in systems that varied from acidic (5.5-5.7) to neutral to slightly alkaline (7-7.3).
The species can tolerate a broad range of temperature which is enough to identify it as eurythermic, since it was found in temperatures that varied from 13 to $30^{\circ} \mathrm{C}$. The highest densities of individuals of $S$. carinata was detected at stations 1 and 2 in February 1995, respectively, in sample units HAS26680 and HAS26684 to HAS26685. Strombomonas carinata was found during summer, winter, and spring.

Strombomonas ferrazi was collected just once (sample unit HAS26735) from water with higher values of nitrogen (ammonium, nitrite, nitrate, and total nitrogen) when compared to those from which $S$. carinata was gathered (Tab. 3). The species occurred during only the winter, in acidic water ( $\mathrm{pH}$ 6.6), and low temperature $\left(17^{\circ} \mathrm{C}\right)$.

Table 3. Physical and chemical characteristics of the water in which representative individuals of $S$. carinata and S. ferrazi occurred.

\begin{tabular}{lcccccc}
\hline & \multicolumn{5}{c}{ S. carinata } & S. ferrazi \\
\cline { 2 - 6 } Variable & 26680 & $26684-5$ & 26745 & 26761 & 26785 & 26735 \\
\hline Ammonium $\left(\mu \mathrm{g} .1^{-1}\right)$ & 15 & 15 & 117 & 81 & 25 & 126 \\
Nitrite $\left(\mu \mathrm{g} .1^{-1}\right)$ & 7 & 7 & 12 & 9 & 2,8 & 42 \\
Nitrate $\left(\mu \mathrm{g} \cdot \mathrm{l}^{-1}\right)$ & 42 & 56 & 186 & 149 & 82 & 222 \\
$\mathrm{pH}$ & 5.5 & 5.7 & 7.4 & 7.3 & 7.0 & 6.6 \\
Water temperature $\left({ }^{\circ} \mathrm{C}\right)$ & 25 & 26 & 13 & 20 & 30 & 17 \\
\hline
\end{tabular}




\section{Bibliographical references}

Balech, E. 1944. Trachelomonas de la Argentina. Annales del Museo Argentino de Ciencias naturales "Bernadino Rivadavia" 41: 223-305.

Bourrelly, P. C. 1970. Les algues d'eau douce: initiation à la systematique, 3: les algues bleues et rouges, les eugléniens, peridiniens et cryptomonadines. Éditions N. Boubée \& Cie., Paris.

Conforti, V.; Walne, P. L. \& Dunlap, J. R. 1994. Comparative ultrastructure and elemental composition of envelopes of Trachelomonas and Strombomonas (Euglenophyta).Acta Protozoologica 33: 71-78.
Deflandre, G. 1930. Strombomonas, nouveau genre d'Euglenacées (Trachelomonas Ehr. pro parte). Archiv Protistenkunde 69: 551-614.

Dunlap, J.R.; Walne, P.L. \& Kivic, P. 1986. Comparative microarchitecture and cytochemistry of envelop of Strombomonas and Trachelomonas. British Phycological Journal 21: 399-405.

Tell, G. \& Conforti, V. 1984. Ultrastructura de la lórica de cuatro especies de Strombomonas Defl. (Euglenophyta) em M.E.B. Nova Hedwigia 40: 123-131.

Tell, G. \& Conforti, V. 1988. Quelques Strombomonas Defl. (Euglenophyta) de l'Argentina au microscope photonique et élétronic à balayage. Nova Hedwigia 46: 541-556. 